\title{
Long-term outcomes of early initiated antiretroviral therapy in sub-Saharan children: A Cameroonian cohort study
}

Francis Ateba Ndongo ( $\square$ atebfranc@gmail.com )

Chantal Biya Foundation https://orcid.org/0000-0002-0745-1715

Mathurin Cyrille TEJIOKEM

Centre Pasteur du Cameroun, Yaoundé

Calixte IDA PENDA

Universite de Douala Faculte de Medecine et Sciences Pharmaceutiques

Suzie TETANG NDIANG

Centre Hospitalier Chretien asbl

Jean-Audrey NDONGO

CIRCB

Georgette GUEMKAM

Centre Mère et Enfant de la Fondation Chantal Biya, Yaoundé

Casimir Ledoux SOFEU

Centre Pasteur du Cameroun, Yaoundé

Paul Alain TAGNOUOKAM-NGOUPO

Centre Pasteur du Cameroun, Yaoundé

ANFUMBOM KFUTWAH

Centre Pasteur du Cameroun, Yaoundé

Philippe MSELLATI

TransVIHMI, IRD, Montpellier

Albert FAYE

Universite Paris Diderot

Josiane WARSZAWSKI

Universite Paris-Sud

Research article

Keywords: HIV-infected children, early initiated antiretroviral treatment, long-term outcomes

Posted Date: May 18th, 2020

DOI: https://doi.org/10.21203/rs.3.rs-29296/v1 
License: (c) (i) This work is licensed under a Creative Commons Attribution 4.0 International License. Read Full License

Version of Record: A version of this preprint was published at BMC Pediatrics on April 21st, 2021. See the published version at https://doi.org/10.1186/s12887-021-02664-6. 


\section{Abstract \\ Background}

In most studies, the virological response is assessed during the first two years of antiretroviral treatment initiated in HIV-infected infants. However, early initiation of antiretroviral therapy exposes infants to very long-lasting treatment. Moreover, maintaining viral suppression in children is difficult. We aimed to assess the virologic response and mortality in HIV-infected children after five years of early initiated antiretroviral treatment (ART) and identify factors associated with virologic success in Cameroon.

\section{Methods}

In this cohort study, we included 149 children who were still alive after two years of early ART. Virologic response was assessed after 5 years of treatment. The probability of maintaining virologic success between two and five years of ART was estimated using Kaplan-Meier curve. Factors associated with a viral load $<400$ copies $/ \mathrm{mL}$ in children still alive at five years of ART were studied using logistic regressions.

\section{Results}

The viral load after five years of early ART was suppressed in 66.8\% [60.1-73.5] of the 144 children still alive and in care. Among the children with viral suppression after two years of ART, the probability of maintaining viral suppression after five years of ART was $64.0 \%$ [54.0-74.0]. The only factor associated with viral suppression after five years of ART was achievement of confirmed virological success within the first two years of ART [OR $=2.7(1.1-6.8) ; p=0.033]$.

\section{Conclusions}

This study reported difficulty in maintaining virologic success in sub-Saharan HIV-infected children between two and five years of early initiated ART. It also highlighted the importance of initial viral suppression for achieving and maintaining virologic success in the long-term.

\section{Background}

Over the last years, the beneficial effects of antiretroviral therapy (ART) have been reported among HIVinfected children (1-4). In addition, early initiation of ART in infants and young children has been proven to be associated with reduced morbidity and mortality (5-13). Based on such evidence, ART treatment guidelines of the World Health Organization (WHO) and various countries have been updated to recommend early initiation of ART in HIV-infected infants (14-17), leading to an increase in child enrolment in sub-Saharan African pediatric ART programs (18-20). 
In most studies, the virologic response is assessed during the first two years following ART initiation of HIV-infected infants (7-10,12,21-28). However, early initiation of ART in vertically HIV-infected children exposes them to a very long-lasting treatment relative to that of adults. Moreover, maintaining viral suppression in children is very difficult $(8,29,30)$. Pediatric ART options are limited in Sub-Saharan Africa $(16,22,31,32)$. Thus long-term success of early infant ART in Sub-Saharan Africa depends on the efficacy of first-line regimens $(33,34)$. There is a need to study longer-term efficacy of early initiated ART in HIVinfected children.

In the ANRS-12140 Pediacam cohort study, Cameroonian HIV-infected children were initiated on ART at a median age of four months $(35,36)$. We aimed to determine the virologic response and mortality after five years of antiretroviral treatment initiated during the first year of life based on data from this cohort study and identify factors associated with virologic success in a sub-Saharan country (Cameroon).

\section{Patients And Methods}

\section{The ANRS-12140 Pediacam Study}

ANRS-12140 Pediacam is a prospective cohort study of HIV-infected children included between November 2007 and October 2011 from three referral hospitals in Cameroon: the "Centre Mère et Enfant de la Fondation Chantal Biya" (CME-FCB) and "Centre Hospitalier d'Essos" (CHE), both in Yaounde, and the "Hôpital Laquintinie de Douala" (HLD) in Douala. Pediacam comprised two phases and has been described previously $(37,38)$. Briefly, during the first phase, infants born to HIV-infected mothers and those born to HIV-uninfected mothers were matched according to gender and site of recruitment during the first week of life and followed until the fourteenth week. All infants received routine vaccines according to the Expanded Program of Immunization at birth, and 6, 10, and 14 weeks. HIV-exposed infants were tested for HIV using molecular tools at six weeks of age. HIV test results were available at 10 weeks with retesting for HIV-positive diagnoses. HIV-negative breastfed infants were retested six weeks after weaning. All HIV-infected infants and subsamples of uninfected HIV-exposed and HIV-unexposed infants were eligible for the second phase of follow-up, planned to continue until five years of age. During the above inclusion period, direct inclusion into the phase 2 follow-up was proposed to the mothers of HIVinfected infants identified and diagnosed after the first week but before seven months of life. Overall, 210 HIV-infected infants were included in this second phase. ART was systematically proposed as soon as the HIV status was confirmed, according to the Cameroonian guidelines at the time of the study: zidovudine (or abacavir or stavudine) + lamivudine, for all infants, combined with ritonavir-boosted lopinavir or nevirapine, depending on the previous history of nevirapine used for prevention of mother-tochild transmission (PMTCT). HIV viral load was measured by RT PCR (Biocentric, Bandol, France) using plasma specimen, with 300 copies/mL as lower limit of quantification from 2007 to 2011. Thereafter, new devices for measuring viral load were acquired with the threshold of 60 copies $/ \mathrm{mL}$ as lower limit of quantification. Data concerning biological and clinical parameters collected at inclusion and every three months after ART initiation until the age of two years and every six months thereafter. At the same timepoints, a standardized questionnaire was administered to caregivers to collect data on family living 
conditions and adherence to ART. Children whose HIV viral load remained high ( $\geq 1000$ copies $/ \mathrm{mL}$ ) for at least three consecutive medical visits were selected for HIV genotypic resistance test to ARVs performed with $1 \mathrm{~mL}$ of plasma using the French ANRS (French National Agency for Research on AIDS and Viral Hepatitis) protocol (39). The targeted regions were Protease and Reverse transcriptase of the HIV polymerase gene. The exams and transport fees were paid by the Pediacam project.

\section{Study population}

Among the 210 HIV-infected children included in phase 2 of the Pediacam study, 149 who initiated ART no later than the age of one year were alive at two years and considered for this analysis (Fig. 1). Data were analyzed from the second to fifth year of ART.

\section{Endpoints}

The main outcome variable for this study was virologic success (VS), defined on the one hand as the achievement of viral load $<400$ copies $/ \mathrm{mL}$ at least once during the period from two to five years after ART initiation, and one the other as the achievement of viral load $<400$ copies $/ \mathrm{mL}$ after five years of ART initiation. This threshold had also been reported in previous studies $(9,24,40-42)$. We also studied mortality and the immune status, defined by the percentage of CD4 lymphocytes, at five years after ART initiation.

Virologic, immunological, and clinical data were analyzed during the visits scheduled every six months from 24 months after ART initiation: month 24 (M24), month 30 (M30), month 36 (M36), month 42 (M42), month 48 (M48), month 54 (M54), and month 60 (M60). A window of three months before and after these time points was accepted for data collection. The monitoring values used were the nearest measurements within these \pm 3 -month intervals. The children still alive who did not attend the scheduled visit were classified as virologic failure with respect to the corresponding visit.

\section{Exposure variables}

We mainly considered characteristics at M24 to identify factors associated with VS at M60: calendar period, ART regimen, site of ART delivery, age and clinical presentation of the child, attainment of confirmed VS (viral load $(\mathrm{VL})<1000$ copies/mL) within the first two years after ART initiation (43), virological status at M24 (viral load $<$ or $\geq 1000$ copies $/ \mathrm{mL}$ ), and immunological status (percentage of CD4 lymphocytes). We also considered variables related to living conditions at M24: people living in the household, access to running water, access to electricity, and availability of a functional refrigerator at home. Finally, we considered the reporting of caregiver adherence (recall of missed doses in the past three days) collected at M60. Children were classified as non-adherent if at least one dose was missed during the past three days $(18,36)$.

\section{Statistical analysis}

The study population was initially divided into two groups by distinguishing their virological status at two years of ART: 1) children who had a viral load < 400 copies/mL at M24 (Group 1) and 2) children who had 
a viral load $\geq 400$ copies $/ \mathrm{mL}$ or whose viral load had not been measured at M24 (15 children of whom the last viral load measured was $\geq 400$ copies/mL at M12) (Group 2).

The probability of maintaining VS from M24 to M60 for group 1 was estimated using the Kaplan-Meier model and the probability of achieving VS for group 2 was estimated using a competing risk regression curve (with death as the competing event).

The association of exposure variables with viral load $<400$ copies $/ \mathrm{mL}$ (versus a viral load $\geq 400$ copies $/ \mathrm{mL}$ ) at M60 for children who were still alive was assessed in univariate and multivariate analysis using logistic regression. The site of ART delivery, virological status at M24, ART regimen at M24, and reporting of caregiver adherence (recall of missed doses in the past three days) at M60 were included in all multivariate models (a priori risk factors). Other exposure variables, with $p \leq 0.20$ in univariate analysis, were also included in the initial multivariate model. The final model was built using backwards elimination, comprising a priori risk factors and other exposure variables with $p \leq 0.20$. All statistical analyses were performed using STATA @ 13.0 (Stata Corp, College Station, TX).

\section{Results}

\section{Study Population}

Among the 149 children ( 82 boys) followed-up and still alive at two years after ART initiation, with first ART treatment started during the first year of life, three quarters $(73.9 \%)$ were enrolled in the two Yaounde sites [Table 1]. The median age of the children at two years after ART initiation (origin of time for this analysis) was 28.5 months [IQR: $27.1-30.0]$. Most (75.6\%) were living with their mothers (with or without their fathers) in households of which $39.4 \%$ had running water, $93.6 \%$ electricity, and $51.1 \%$ a functional refrigerator. The ART regimen two years after treatment initiation was comprised of lopinavir boosted with ritonavir (74.5\%) or nevirapine (25.5\%), with a median percentage of CD4 lymphocytes of $33.6 \%$ [24.1-40.4]. 
Table 1

Baseline characteristics of HIV-infected children alive at 24 months after early antiretroviral treatment initiation (ANRS-Pediacam Study, 2008-2013, Cameroon) ( $N=149$ )

\begin{tabular}{|c|c|c|}
\hline & $\mathbf{N}$ & $\begin{array}{l}\%(n) \text { or median } \\
\text { (IQR) }\end{array}$ \\
\hline Male & 149 & $55.0(82)$ \\
\hline Site of ART delivery & 149 & \\
\hline CME/FCB & & $51.7(77)$ \\
\hline HLD & & $22.2(33)$ \\
\hline $\mathrm{CHE}$ & & $26.1(39)$ \\
\hline \multicolumn{3}{|l|}{ At 24 months after ART initiation (Study start) } \\
\hline Age at 2 years after ART initiation & 149 & \\
\hline$\nabla 28$ months (treatment initiated before age 4 months of age) & & $50.3(75)$ \\
\hline [28-30[ months (treatment initiated between age 4 and 6 months) & & $30.2(45)$ \\
\hline$\geq 30$ months (treatment initiated from 6 months of age) & & $19.5(29)$ \\
\hline Median in months (QR) & & $28.5(27.1-30.0)$ \\
\hline Time period & 149 & \\
\hline $2010-2011$ & & $65.1(97)$ \\
\hline $2012-2013$ & & $34.9(52)$ \\
\hline ART regimen & 149 & \\
\hline Lopinavir-based & & $74.5(111)$ \\
\hline Nevirapine-based & & $25.5(38)$ \\
\hline Children living with & 131 & \\
\hline Both parents & & $38.9(51)$ \\
\hline Mother only & & $36.7(48)$ \\
\hline Father only & & $5.3(7)$ \\
\hline Other relatives & & $19.1(25)$ \\
\hline Family size $\leq 5$ people & 94 & $47.9(45)$ \\
\hline Access at child's home to & 94 & \\
\hline
\end{tabular}

$\mathrm{N}$ : total number of subjects; $\mathrm{n}$ : number of subjects in the category; ART: antiretroviral therapy; CME/FCB: Centre Mère et Enfant de la Fondation Chantal Biya; HLD: Hôpital Laquintinie de Douala; CHE: Centre Hospitalier d'Essos; IQR: interquartile range; VL: viral load. 


\begin{tabular}{|c|c|c|}
\hline & $\mathbf{N}$ & $\begin{array}{l}\%(n) \text { or median } \\
(\text { IQR) }\end{array}$ \\
\hline Refrigerator & & $51.1(48)$ \\
\hline Running water & & $39.4(37)$ \\
\hline Electricity & & $93.6(88)$ \\
\hline CD4 percentage at 2 years after ART initiation & 131 & \\
\hline$\nabla 15$ & & $6.1(8)$ \\
\hline$[15-20[$ & & $6.1(8)$ \\
\hline $20-25[$ & & $14.5(19)$ \\
\hline$\geq 25$ & & $73.3(96)$ \\
\hline Not measured & & 13 \\
\hline Median (QR), N = 131 & & $33.6(24.5-41.6)$ \\
\hline \multicolumn{3}{|l|}{ Virological status } \\
\hline $\begin{array}{l}\text { Achievement of confirmed virological success (CVS) within the first two } \\
\text { years of ART }\end{array}$ & 149 & \\
\hline Yes (= $2 \mathrm{VL}<1000$ copies/mL for two consecutive measurements) & & $77.2(115)$ \\
\hline No & & $22.8(34)$ \\
\hline Virological status at 2 years ( \pm 3 months) after ART initiation & 134 & \\
\hline VL $\otimes 400$ copies $/ \mathrm{mL}$ & & $67.2(90)$ \\
\hline $\mathrm{VL} \geq 400$ copies $/ \mathrm{mL}$ & & $32.8(44)$ \\
\hline VL not measured & & 15 \\
\hline Last viral load if not available at 2 years \pm 3 months after ART initiation & 15 & \\
\hline VL $\otimes 400$ copies $/ \mathrm{mL}$ & & 12 \\
\hline $\mathrm{VL} \geq 400$ copies $/ \mathrm{mL}$ & & 3 \\
\hline \multicolumn{3}{|c|}{$\begin{array}{l}\text { N: total number of subjects; n: number of subjects in the category; ART: antiretroviral therapy; } \\
\text { CME/FCB: Centre Mère et Enfant de la Fondation Chantal Biya; HLD: Hôpital Laquintinie de Douala; } \\
\text { CHE: Centre Hospitalier d'Essos; IQR: interquartile range; VL: viral load. }\end{array}$} \\
\hline
\end{tabular}

At two years after ART initiation, most of the children (77.2\%) had achieved a confirmed VS at least once (43) and a viral load measurement was available for 134 , of whom $67.2 \%$ were $<400$ copies $/ \mathrm{mL}$ («controlled viral load»). Among the 15 other children, the last available viral load was $\geq 400 \mathrm{copies} / \mathrm{mL}$ for 12. 
We compared the characteristics at two years of treatment according to a viral load below or above 400 copies/mL by grouping together the children whose viral load was $\geq 400$ copies $/ \mathrm{mL}$ or not measured. The children with VS at two years of treatment were more often girls than boys $(62.2 \%$ versus $37.8 \%, \mathrm{p}=$ 0.017) and almost all (96.7\%) had achieved confirmed virological success (CVS) at least once before two years of treatment, whereas this was true for only $45.5 \%$ of the other children $(p<0.001)$.

\section{Mortality and retention in care between two and five years after ART initiation}

Among the 149 children, alive at two years of treatment, included in this study, a viral load measurement was available at M60 for 121 (84.0\%) and $23(15.4 \%)$ did not have viral load measurements at five years of ART with no information concerning death [Table 2]. Of these, 12 (8.1\%) were lost to follow-up before M24. Five (3.4\%) deaths were recorded M24 and M60, corresponding to a death rate of $3.0 \%$ [95\% $\mathrm{Cl}: 0.2 \%$ - 5.8\%] estimated using the Kaplan Meier method. Among them, two occurred in children with a viral load $\geq 400$ copies $/ \mathrm{mL}$ and three in children whose viral load was unavailable at two years of treatment, whereas there were no deaths among children with VS at two years of treatment. 
Table 2

Mortality and immuno-virological status at 5 years (+/-3 months) of children with antiretroviral treatment initiated within the first year of life (ANRS-Pediacam Study, 2008-2013, Cameroon) $(\mathrm{N}=149)$

Viral load at 2 years (+/- 3 months) of antiretroviral treatment initiation

\begin{tabular}{|c|c|c|c|c|c|c|c|c|}
\hline & \multicolumn{2}{|c|}{$\begin{array}{l}\text { All } \\
N=149\end{array}$} & \multicolumn{2}{|c|}{$\begin{array}{l}<400 \\
\text { copies/mL } \\
\mathrm{N}=90\end{array}$} & \multicolumn{2}{|c|}{$\begin{array}{l}\geq 400 \\
\text { copies/mL } \\
\mathrm{N}=44\end{array}$} & \multicolumn{2}{|c|}{$\begin{array}{l}\text { Absence } \\
\text { of viral } \\
\text { load } \\
\mathrm{N}=15\end{array}$} \\
\hline & $\mathbf{N}$ & $\%$ & $\mathbf{N}$ & $\%$ & $\mathbf{N}$ & $\%$ & $\mathbf{N}$ & $\%$ \\
\hline \multicolumn{9}{|l|}{$\begin{array}{l}\text { Death between } 2 \text { and } 5 \text { years of } \\
\text { ART initiation }\end{array}$} \\
\hline Yes & 5 & 3.4 & 0 & 0.0 & 2 & 8.5 & 3 & 20.0 \\
\hline No & 144 & 94.6 & 90 & 100.0 & 42 & 91.5 & 12 & 80.0 \\
\hline \multicolumn{9}{|l|}{$\begin{array}{l}\text { Virological status at } 5 \text { years } \\
(+/-3 \text { months) after ART } \\
\text { initiation }\end{array}$} \\
\hline $\mathrm{VL}<400$ copies $/ \mathrm{mL}$ & 99 & 66.4 & 68 & 75.6 & 28 & 63.6 & 3 & 20.0 \\
\hline $\mathrm{VL} \geq 400$ copies $/ \mathrm{mL}$ & 22 & 14.8 & 9 & 10.0 & 12 & 27.3 & 1 & 6.7 \\
\hline $\begin{array}{l}\text { Absence of VL if not dead at } \\
\text { M60 }\end{array}$ & 23 & 15.4 & 13 & 14.4 & 2 & 4.6 & 8 & 53.3 \\
\hline \multicolumn{9}{|l|}{$\begin{array}{l}\text { Probability at } 5 \text { years } \\
(+/-3 \text { months }) \text { after ART } \\
\text { initiation, using Kaplan-Meier } \\
\text { estimation method }\end{array}$} \\
\hline $\begin{array}{l}\text { Of maintaining virological } \\
\text { success (Group 1) }\end{array}$ & 90 & 64.0 & (ents) & & & & & \\
\hline $\begin{array}{l}\text { Of achieving at least once } \mathrm{VL}< \\
400 \text { copies } / \mathrm{mL} \text { (Group 2) }\end{array}$ & 44 & 76.0 & (ents) & & & & & \\
\hline \multicolumn{9}{|l|}{$\begin{array}{l}\text { CD4 percentage at } 5 \text { years of } \\
\text { ART initiation }\end{array}$} \\
\hline$<15$ & 1 & 0.7 & 0 & 0.0 & 1 & 2.3 & 0 & 0.0 \\
\hline$[15-20[$ & 0 & 0.0 & 0 & 0.0 & 0 & 0.0 & 0 & 0.0 \\
\hline$[20-25[$ & 7 & 4.7 & 5 & 5.6 & 1 & 2.3 & 1 & 6.7 \\
\hline$\geq 25$ & 115 & 77.2 & 74 & 82.2 & 38 & 63.6 & 3 & 20.0 \\
\hline
\end{tabular}

$\mathrm{N}$ : total number of subjects; $\mathrm{n}$ : number of subjects in the category; ART: antiretroviral therapy; IQR: interquartile range; VL: viral load; M60: 60 months of ART initiation; 95\% Cl: 95\% confidence interval. 
Viral load at 2 years (+/- 3 months) of

antiretroviral treatment initiation

Not measured if not dead at M60

$21 \quad 14.1$

$11 \quad 12.2$

2

4.6

8

53.3

$\mathrm{N}$ : total number of subjects; n: number of subjects in the category; ART: antiretroviral therapy; IQR: interquartile range; VL: viral load; M60: 60 months of ART initiation; $95 \% \mathrm{Cl}$ : 95\% confidence interval.

\section{Immunological status at five years of antiretroviral treatment}

Among the children included in this study, almost three quarters had a high CD4 percentage level ( $\geq 25 \%)$ at 5 years of ART (Table 2).

\section{Virologic control at five years of antiretroviral treatment}

Virologic control at five years of ART was estimated at 66.8\% [60.1-73.5] among the 144 children still alive after five years of treatment but 23 (16.0\%) did not have an available viral load measurement at that deadline [Table 2]. Among the children who were virologically controlled (viral load $<400 \mathrm{copies} / \mathrm{mL}$ ) at two years of treatment, the probability of maintaining virologic control at five years, estimated using the Kaplan-Meier method, was 64.0\% [54.0-74.0] [Table 2, Fig. 2]. Of those whose viral load was uncontrolled or unknown at two years of ART, the probability of achieving a viral load $<400 \mathrm{copies} / \mathrm{mL}$ between two and five years was $76.0 \%(63.0-89.0)$.

HIV genotypic resistance test to ARVs was performed for a sample of 25 children whose viral load remained high ( $\geq 1000$ copies $/ \mathrm{mL}$ ) for at least three consecutive medical visits during the study. Of these, 15 (60.0\%) were boys and 18 (72.0\%) have initiated lopinavir-based ART. The distribution of sex and type of ART in this sample was comparable to the study population. Among these children, 5 (20.0\%) rebounded to viral load $\geq 1,000$ copies/mL during the study period for at least 3 consecutive visits before suppressing to viral load < 400 copies/mL no later than five years of ART. Overall, respectively 14 (56.0\%), $9(36.0 \%)$ and $2(8.0 \%)$ of these children had no resistance, only lamivudine (3TC) resistance (not altering the effectiveness of current ART regimen) and resistance to non-3TC drugs (altering the effectiveness of current ART regimen). The resistance pattern did not differ by whether the child was suppressed or not 5 years of ART, according to the Fisher exact test $(p=0.440)$.

\section{Factors associated with virological success at five years of antiretroviral treatment}

In univariate analysis [Table 3], VS at five years of treatment (viral load $<400 \mathrm{copies} / \mathrm{mL}$ versus viral load $\geq 400$ copies/mL or not measured) was associated with female gender [OR = $2.1(1.0-4.4), p=0.041]$ and achievement of confirmed virological success (at least two consecutive viral loads $<400 \mathrm{copies} / \mathrm{mL}$ during the first two years of treatment) at least once within the first two years of ART [OR = 3.0 (1.3-6.9), $\mathrm{p}=0.010]$. There was a non-significant association between VS at M60 and controlled viral load (VL $<400$ copies $/ \mathrm{mL}$ ) at two years of ART initiation [OR = $2.2(0.9-4.8), p=0.061]$, being followed at "Centre 
Hospitalier d'Essos" versus "Centre Mère et Enfant de Yaoundé" and "Hôpital Laquintinie de Douala" [OR $=2.8(1.0-7.6), p=0.056]$ and absence of missed doses during the last three days before the M60 visit [OR $=2.8(0.9-8.7), p=0.076]$. In multivariate analysis [Table 5], the only factors associated with VS at five years of treatment was achievement of confirmed virological success at least once within the first two years of ART [adjusted OR = $2.7(1.1-6.8) ; p=0.033$ ] and the trend between VS and absence of missed doses during the last three days before the M60 visit remained [adjusted $O R=2.7(0.9-10.4), p=$ 0.075]. 
Table 3

Factors associated with virological success (Viral load $<400$ copies $/ \mathrm{mL}$ versus $>400 \mathrm{copies} / \mathrm{mL}$ or not measured) in HIV-infected children at 5 years after early antiretroviral treatment initiation (ANRS-

Pediacam Study, 2008-2013, Cameroon)

Baseline characteristics at 2 years $+/-3$ months after ART initiation
Univariate analysis

$\mathrm{VL}<400 \mathrm{cp} / \mathrm{mL}$ at 5 years $+/-$

3 months after ART initiation
Multivariate analysis

(logistic regression)

$\begin{array}{llllllll}\mathrm{N} & \mathrm{n} & \% & \begin{array}{l}\text { Crude } \\ \text { OR } \\ (95 \% \mathrm{Cl})\end{array} & \mathrm{p} & \begin{array}{l}\text { Adjusted } \\ \text { OR }\end{array} & \mathrm{p} & \mathrm{N} 2 \\ & & & (95 \% \mathrm{Cl}) & & \\ \end{array}$

142

\section{Gender}

Male

65

$\begin{array}{lll}39 & 60.0 & 1\end{array}$

0.041

0.122

Female

79

$\begin{array}{ll}60 & 76.0\end{array}$

2.1

1.9

(1.0-

(0.9-

4.4)

4.2)

\section{Site of ART delivery}

CME/FCB

74

47

63.5

1

0.056

1

0.102

HLD

30

$30 \quad 19$

63.3

\section{8}

(0.3-

18)

0.7

(0.3-

2.8

CHE

40

33

82.5

$(1.0-$
$7.6)$

2.4

(0.8-

$7.2)$

\section{Age}

$₫ 28$ months (treatment

initiated before age of 4

months)

$\geq 28$ months(treatment

initiated from age of 4

months)

$\begin{array}{lllll}72 & 50 & 69.4 & 1 & 0.855\end{array}$

\section{Calendar period}

2010-2011

91

72

49

68.1

0.9

(0.5-

1.9)

\section{2-2013}

$\begin{array}{llll}91 & 63 & 69.2 & 1 \\ 53 & 36 & 67.9 & \begin{array}{l}1.0 \\ (0.5- \\ 2.0)\end{array}\end{array}$

0.923

0.206

(0.5)

\section{8}

(0.7-

4.4)

Virological response within

the first two years of ART 
Baseline characteristics at 2 years $+/-3$ months after ART initiation
Univariate analysis

$\mathrm{VL}<400 \mathrm{cp} / \mathrm{mL}$ at 5 years +/3 months after ART initiation
Multivariate analysis

(logistic regression)

\section{Absence of confirmed \\ virological success}

Achievement of confirmed

virological success at least

once $(=2 \mathrm{VL}<1000$

copies/mL for two

consecutive measurements)

Virological status

$\mathrm{VL} \geq 400$ copies/mL or not measured

VL $₫ 400$ copies $/ \mathrm{mL}$
Crude

$(95 \% \mathrm{Cl})$ $\begin{array}{lllllll}29 & 15 & 51.7 & 1 & 0.010 & 1 & 0.033\end{array}$

$\begin{array}{llll}115 & 84 & 73.0 & 3.0\end{array}$

$(1.3-\quad(1.1-$

6.9)
Adjusted p

$(95 \% \mathrm{Cl})$ 
Baseline characteristics at 2 years +/- 3 months after ART initiation
Univariate analysis

$\mathrm{VL}<400 \mathrm{cp} / \mathrm{mL}$ at 5 years +/3 months after ART initiation
Multivariate analysis

(logistic regression)

$\begin{array}{llllllll}\mathrm{N} & \mathrm{n} & \% & \begin{array}{l}\text { Crude } \\ \text { OR } \\ (95 \% \mathrm{Cl})\end{array} & \mathrm{p} & \begin{array}{l}\text { Adjusted } \\ \text { OR }\end{array} & \mathrm{p} & \mathrm{N} 2 \\ & & & (95 \% \mathrm{Cl}) & & \\ & & & \end{array}$

History of hospitalization, diarrhea, infectious disease, or convulsions within the last 3 months before the M60 visit

$\begin{array}{llllll}\text { No } & 75 & 59 & 78.7 & 1 & 0.975 \\ \text { Yes } & 45 & 37 & 82.2 & \begin{array}{l}1.0 \\ (0.5-\end{array} & \\ & & & 2.3) & \end{array}$

CD4 percentage ${ }^{(2)}$

\begin{tabular}{|c|c|c|c|c|}
\hline$\nabla 25 \%$ & 30 & 29 & 96.2 & 1 \\
\hline$\geq 25 \%$ & 89 & 70 & 78.7 & $\begin{array}{l}0.5 \\
(0.2- \\
1.5)\end{array}$ \\
\hline
\end{tabular}

\section{ART regimen}

Lopinavir-based $\begin{array}{llll}106 & 77 & 72.6 & 1\end{array}$

$0.117 \quad 1$

0.155

Nevirapine-based

$\begin{array}{lll}38 & 22 & 57.9\end{array}$

0.5

$(0.2-$

0.5

(0.2-

1.3)

Number of missed doses

within the last 3 days before

M60 visit

\begin{tabular}{|c|c|c|c|c|c|}
\hline$\geq 1$ missed dose & 95 & 77 & 81.1 & 1 & 0.076 \\
\hline No missed dose & 30 & 22 & 73.3 & $\begin{array}{l}2.8 \\
(0.9- \\
8.7)\end{array}$ & \\
\hline
\end{tabular}

VL: viral load; ART: antiretroviral therapy: OR : odds ratio; $95 \% \mathrm{Cl}$ : $95 \%$ confidence interval; N: total number of subjects at 5 years after treatment initiation; $\mathbf{n}$ : number of subjects with virological success at 5 years after treatment initiation; $\mathbf{p}$ : statistical test; $\mathbf{N} 2$ : total number of subjects in final multivariate model; VL: viral load; (1): Variable excluded from the univariate and multivariate analyses because of unbalanced sizes of categories; (2): Variables excluded from the multivariate analysis because of collinearity with virological status at 2 years after treatment initiation.

\section{Discussion}


The proportion of VS among children still alive and followed-up at five years of treatment, initiated before the age of 12 months, was $66.8 \%$ [60.1-73.5], comparable to the results reported for Italian children who initiated ART early (44), and adult populations (45). However, this result contrasts with a lower proportion of VS reported in a study conducted in Ivoirian children who initiated ART at a higher median age (36 months versus 4 months in our study) (46).

Among children alive at two years of treatment, $23(15.4 \%)$ did not have viral load measurements at five years and there was no information concerning death, despite active telephone recalls of non-returning families (47). The low mortality beyond the first two years of antiretroviral treatment [3.3\% $(95 \% \mathrm{Cl}: 0.4-$ 6.2)] is coherent with the results of other studies conducted in children and adults, for which most of the deaths occurred during the first year of ART $(9,28,45,48-50)$. The high mortality observed in the cohort before age 2 years of ART may reflect the rapid progression of the disease in infants enrolled in medical care after severe immunodeficiency had set in (43).

The probability of maintaining VS between two and five years of ART, estimated at $64.0 \%$ [54.0-74.0], highlights the difficulty of parents to administer drugs daily to their children (43). The only factor independently associated with a controlled viral load $(<400$ copies $/ \mathrm{mL})$ at five years of treatment was the existence of VS at two years of treatment, irrespective of living conditions. The association with VS at two years of ART may be related to factors that favor long-term family adherence to ART or favorable immunological or virological factors in these children (51).

One of the strengths of our study was the use of data from a prospective cohort of children, with scheduled determinations of viral load at six-month intervals, making it possible to use survival models. The current missed doses self-reported by the child caregiver may not be a good stool for detecting virological success at 5 years of ART since it does not reflect the longitudinal adherence evolvement. However, it has been demonstrated previously that the negative predictive value of current missed dose in detecting virological success (36) was as satisfactory as cumulative missed doses (around 75\%). In fact, virological response seems to be mostly influenced by adherence status within the last three months, especially when there is no drug resistance. The non-significant association between the absence of missed doses during the last three days before the M60 visit and virological success at this deadline would become significant if the study population size was larger. This hypothesis would confirm the difficulty of parents to administer daily medications to their children, given the difficulty in this study to maintain virologic suppression in children who had initiated ART early during infancy. We did not obtain exhaustive genotyping results for all the children in this study. However, the HIV-resistance patterns were similar, irrespective of virological status at five years of treatment, among the 25 children who were tested for genotyping. However, it is not possible to draw conclusions on the effect of HIV resistance mutations on the virological response at five years of ART early initiated during infancy because the study was not sufficiently powered to address this issue.

\section{Conclusions}


This study reported difficulty in maintaining virologic success in sub-Saharan HIV-infected children between two and five years of early initiated ART. It also highlighted the importance of initial viral suppression for achieving and maintaining virologic success in the long-term. Further studies should focus on an exhaustive assessment of long-term HIV resistance profiles in children who initiated ART early during infancy.

\section{Declarations}

\section{Ethics approval and consent to participate}

The ANRS-Pediacam study was granted ethical approval in Cameroon by the National Ethics Committee and in France by the Biomedical Research Committee of the Pasteur Institute of Paris. Parents signed written informed consent for participation in the study.

\section{Consent for publication}

Not applicable.

\section{Availability of data and materials}

The datasets used and/or analysed during the current study are available from the corresponding author on reasonable request.

\section{Competing interests}

The authors have no conflicts of interest relevant to this article to disclose.

\section{Funding}

The Pediacam study was funded by the French National Agency for Research on AIDS and Viral Hepatitis (ANRS) and Total Foundation.

\section{Authors' contributions}

Francis ATEBA NDONGO participated in the study design and conception, the recruitment and follow up of HIV-infected infants, the data analysis and the manuscript writing. Mathurin Cyrille TEJIOKEM participated in the study design and conception, the data analysis, the manuscript writing and the study coordination. Calixte IDA PENDA participated in the study design and conception, the recruitment and 
follow up of HIV-infected infants and the manuscript writing. Suzie TETANG NDIANG, Jean Audrey NDONGO and Georgette GUEMKAM participated in the recruitment and follow up of HIV-infected infants and the manuscript writing. ANFUMBOM KFUTWAH participated in the study design and conception, manuscript writing and the study coordination. Casimir Ledoux SOFEU participated in data analysis and the manuscript writing. Albert FAYE and Josiane WARSZAWSKI participated in the study design and conception, the data analysis, the manuscript writing and the study coordination. Paul Alain TAGNOUOKAM-NGOUPO and Philippe MSELLATI participated in the data analysis and the manuscript writing.

All authors approved the final manuscript as submitted and agree to be accountable for all aspects of the work.

\section{Acknowledgements}

We are grateful to all the members of the Pediacam study group for their commitment to the success of this study. We thank the parents who agreed to inclusion of their children in this study.

\section{References}

1. Judd A, Doerholt K, Tookey PA, Sharland M, Riordan A, Menson E, et al. Morbidity, mortality, and response to treatment by children in the United Kingdom and Ireland with perinatally acquired HIV infection during 1996-2006: planning for teenage and adult care. Clin Infect Dis Off Publ Infect Dis Soc Am 1. oct 2007;45(7):918-24.

2. Brady MT, Oleske JM, Williams PL, Elgie C, Mofenson LM, Dankner WM, et al. Declines in Mortality Rates and Changes in Causes of Death in HIV-1-Infected Children during the HAART Era. J Acquir Immune Defic Syndr 1999. 1 janv 2010;53(1):86-94.

3. de Martino M, Tovo PA, Balducci M, Galli L, Gabiano C, Rezza G, et al. Reduction in mortality with availability of antiretroviral therapy for children with perinatal HIV-1 infection. Italian Register for HIV Infection in Children and the Italian National AIDS Registry. JAMA. 12 juill 2000;284(2):190-7.

4. Janssens B, Raleigh B, Soeung S, Akao K, Te V, Gupta J, et al. Effectiveness of Highly Active Antiretroviral Therapy in HIV-Positive Children: Evaluation at 12 Months in a Routine Program in Cambodia. Pediatrics 1 nov. 2007;120(5):e1134-40.

5. Violari A, Cotton MF, Gibb DM, Babiker AG, Steyn J, Madhi SA, et al. Early antiretroviral therapy and mortality among HIV-infected infants. N Engl J Med. nov 2008;20(21):2233-44. 359(.

6. Goetghebuer T, Haelterman E, Le Chenadec J, Dollfus C, Gibb D, Judd A, et al. Effect of early antiretroviral therapy on the risk of AIDS/death in HIV-infected infants: AIDS. mars 2009;23(5):597604.

7. Purchase SE, Van der Linden DJ, McKerrow NH. Feasibility and effectiveness of early initiation of combination antiretroviral therapy in HIV-infected infants in a government clinic of Kwazulu-Natal, 
South Africa. J Trop Pediatr avr. 2012;58(2):114-9.

8. Meyers TM, Yotebieng M, Kuhn L, Moultrie H. Antiretroviral therapy responses among children attending a large public clinic in Soweto, South Africa. Pediatr Infect Dis J nov. 2011;30(11):974-9.

9. Tukei VJ, Murungi M, Asiimwe AR, Migisha D, Maganda A, Bakeera-Kitaka S, et al. Virologic, immunologic and clinical response of infants to antiretroviral therapy in Kampala, Uganda. BMC Pediatr. 2013;13:42.

10. Sauvageot D, Schaefer M, Olson D, Pujades-Rodriguez M, O’Brien DP. Antiretroviral therapy outcomes in resource-limited settings for HIV-infected children $<5$ years of age. Pediatrics mai. 2010;125(5):e1039-47.

11. Aboulker J-P, Babiker A, Chaix ML, Compagnucci A, Darbyshire J, Debré M, et al. Highly active antiretroviral therapy started in infants under 3 months of age: 72-week follow-up for CD4 cell count, viral load and drug resistance outcome. AIDS Lond Engl 23 janv. 2004;18(2):237-45.

12. Eley B, Davies M-A, Apolles P, Cowburn C, Buys H, Zampoli M, et al. Antiretroviral treatment for children. South Afr Med J Suid-Afr Tydskr Vir Geneeskd sept. 2006;96(9 Pt 2):988-93.

13. Chiappini E, Galli L, Tovo P-A, Gabiano C, Gattinara GC, Guarino A, et al. Virologic, immunologic, and clinical benefits from early combined antiretroviral therapy in infants with perinatal HIV-1 infection. AIDS janv. 2006;20(2):207-15.

14. WHO. Antiretroviral therapy of HIV infection in infants and children: towards universal access. Geneva: World Health Organization; 2006.

15. WHO. Antiretroviral Therapy for HIV Infection in Infants and Children

: Towards Universal Access: Recommendations for a Public Health Approach: 2010 Revision [Internet]

[cité 21 nov 2014]. (WHO Guidelines Approved by the Guidelines Review Committee) WHO. Antiretroviral Therapy for HIV Infection in Infants and Children: Towards Universal Access: Recommendations for a Public Health Approach: 2010 Revision [Internet]. Geneva: World Health Organization; 2010 [cité 21 nov 2014]. (WHO Guidelines Approved by the Guidelines Review Committee). Disponible sur: http://www.ncbi.nlm.nih.gov/books/NBK138576/.

16. OMS | Lignes directrices unifiées sur

l'utilisation des antirétroviraux pour le traitement et la prévention de l'infection à VIH [Internet] [cité 9 mars 2016]. Disponible sur:

OMS | Lignes directrices unifiées sur. l'utilisation des antirétroviraux pour le traitement et la prévention de l'infection à VIH [Internet]. [cité 9 mars 2016]. Disponible sur: http://www.who.int/hiv/pub/guidelines/arv2013/download/fr/.

17. Doherty M, Ford N, Vitoria M, Weiler G, Hirnschall G. The 2013 WHO guidelines for antiretroviral therapy: evidence-based recommendations to face new epidemic realities. Curr Opin HIV AIDS nov. 2013;8(6):528-34.

18. Davies M-A, Boulle A, Fakir T, Nuttall J, Eley B. Adherence to antiretroviral therapy in young children in Cape Town, South Africa, measured by medication return and caregiver self-report: a prospective 
cohort study. BMC Pediatr. 2008;8:34.

19. WHO | Progress report 2011. Global HIV/AIDS response [Internet]. WHO. [cité 13 avr 2016]. Disponible sur: http://www.who.int/hiv/pub/progress_report2011/en/.

20. Fact sheet 2015 | UNAIDS [Internet]. [cité 8 mars 2016]. Disponible sur: http://www.unaids.org/en/resources/campaigns/HowAIDSchangedeverything/factsheet.

21. Goetghebuer T, Le Chenadec J, Haelterman E, Galli L, Dollfus C, Thorne C, et al. Short- and Long-term Immunological and Virological Outcome in HIV-Infected Infants According to the Age at Antiretroviral Treatment Initiation. Clin Infect Dis 15 mars. 2012;54(6):878-81.

22. WHO I. Scaling up priority HIV/AIDS interventions in the health sector [Internet]. WHO. [cité 10 déc 2015]. Disponible sur: http://www.who.int/hiv/pub/2010progressreport/report/en/.

23. Porter M, Davies M-A, Mapani MK, Rabie H, Phiri S, Nuttall J, et al. Outcomes of Infants Starting Antiretroviral Therapy in Southern Africa, 2004-2012. J Acquir Immune Defic Syndr 1999. 15 août 2015;69(5):593-601.

24. Duong T, Judd A, Collins IJ, Doerholt K, Lyall H, Foster C, et al. Long-term virological outcome in children on antiretroviral therapy in the UK and Ireland. AIDS Lond Engl 23 oct. 2014;28(16):2395405.

25. Collaboration of Observational HIV Epidemiological Research Europe (COHERE) Study Group. Sabin CA, Smith CJ, d'Arminio Monforte A, Battegay M, Gabiano C, et al. Response to combination antiretroviral therapy: variation by age. AIDS Lond Engl 31 juill 2008;22(12):1463-73.

26. Ndondoki C, Dicko F, Ahuatchi Coffie P, Kassi Eboua T, Koumavi Ekouevi D, Kouadio K, et al. Antiretroviral treatment response of HIV-infected children after prevention of mother-to-child transmission in West Africa. J Int AIDS Soc [Internet]. 6 févr 2014 [cité 29 avr 2016];17(1). Disponible sur: http://www.jiasociety.org/index.php/jias/article/view/18737.

27. The European Pregnancy and Paediatric HIV Cohort Collaboration (EPPICC) study group in EuroCoord. Response to early antiretroviral therapy in HIV-1 infected infants in Europe, 1996-2008. AIDS Lond Engl 28 nov. 2011;25(18):2279-87.

28. Walker AS, Doerholt K, Sharland M, Gibb DM, Collaborative HIV, Paediatric Study (CHIPS) Steering Committee. Response to highly active antiretroviral therapy varies with age: the UK and Ireland Collaborative HIV Paediatric Study. AIDS Lond Engl 24 sept. 2004;18(14):1915-24.

29. van Rossum AMC, Fraaij PLA, de Groot R. Efficacy of highly active antiretroviral therapy in HIV-1 infected children. Lancet Infect Dis févr. 2002;2(2):93-102.

30. Fraaij PLA, Verweel G, van Rossum AMC, van Lochem EG, Schutten M, Weemaes CMR, et al. Sustained viral suppression and immune recovery in HIV type 1-infected children after 4 years of highly active antiretroviral therapy. Clin Infect Dis Off Publ Infect Dis Soc Am 15 févr. 2005;40(4):604-8.

31. American Academy of Pediatrics Committee on Pediatric AIDS, Section on International Child Health. Havens PL, Gibb DM. Increasing antiretroviral drug access for children with HIV infection. Pediatrics avr 2007;119(4):838-45. 
32. Church JD, Omer SB, Guay LA, Huang W, Lidstrom J, Musoke P, et al. Analysis of nevirapine (NVP) resistance in Ugandan infants who were HIV-infected despite receiving single dose (SD) nevirapine (NVP) vs. SD NVP plus daily NVP up to 6-weeks of age to prevent HIV vertical transmission. J Infect Dis 1 oct. 2008;198(7):1075-82.

33. Fitzgerald F, Penazzato M, Gibb D. Development of Antiretroviral Resistance in Children With HIV in Low- and Middle-Income Countries. J Infect Dis 15 juin. 2013;207(suppl 2):85-92.

34. Sigaloff KCE, Calis JCJ, Geelen SP, van Vugt M, de Wit TFR. HIV-1-resistance-associated mutations after failure of first-line antiretroviral treatment among children in resource-poor regions: a systematic review. Lancet Infect Dis oct. 2011;11(10):769-79.

35. Tejiokem MC, Warszawski J, Ateba Ndongo F, Tetang Ndiang S, Ndongo JA, Owona F, et al. Feasibility of Routinely Offering Early Combined Antiretroviral Therapy to HIV-infected Infants in a Resource-limited Country: The ANRS-PediaCAM Study in Cameroon. Pediatr Infect Dis J oct. 2015;34(10):e248-53.

36. Ateba Ndongo F, Warszawski J, Texier G, Penda I, Tetang Ndiang S, Ndongo J-A, et al. Could caregiver reporting adherence help detect virological failure in Cameroonian early treated HIV-infected infants? BMC Pediatr. 2015;15(1):132.

37. Tejiokem MC, Faye A, Penda IC, Guemkam G, Ateba Ndongo F, Chewa G, et al. Feasibility of early infant diagnosis of HIV in resource-limited settings: the ANRS 12140-PEDIACAM study in Cameroon. PloS One. 2011;6(7):e21840.

38. Tejiokem MC, Warszawski J, Ateba Ndongo F, Tetang Ndiang S, Ndongo JA, Owona F, et al. Feasibility of Routinely Offering Early Combined Antiretroviral Therapy to HIV-infected Infants in a Resource-limited Country: The ANRS-PediaCAM Study in Cameroon. Pediatr Infect Dis J oct. 2015;34(10):e248-53.

39. HIV French Resistance - HIV

-1 genotypic drug resistance interpretation's algorithms [Internet]. [cité 24 nov 2019] HIV French Resistance - HIV-1 genotypic drug resistance interpretation's algorithms [Internet]. [cité 24 nov 2019]. Disponible sur: http://www.hivfrenchresistance.org/.

40. Musoke PM, Mudiope P, Barlow-Mosha LN, Ajuna P, Bagenda D, Mubiru MM, et al. Growth, immune and viral responses in HIV infected African children receiving highly active antiretroviral therapy: a prospective cohort study. BMC Pediatr. 2010;10(1):56.

41. Schoffelen AF, Wensing AMJ, Tempelman HA, Geelen SPM, Hoepelman AIM, Barth RE. Sustained Virological Response on Second-Line Antiretroviral Therapy following Virological Failure in HIVInfected Patients in Rural South Africa. Sluis-Cremer N, éditeur. PLoS ONE. 11 mars 2013;8(3):e58526.

42. Fielding KL, Charalambous S, Stenson AL, Pemba LF, Martin DJ, Wood R, et al. Risk factors for poor virological outcome at 12 months in a workplace-based antiretroviral therapy programme in South Africa: A cohort study. BMC Infect Dis. 2008;8(1):93. 
43. Ateba Ndongo F, Texier G, Ida Penda C, Tejiokem MC, Tetang Ndiang S, Ndongo J-A, et al. Virologic Response to Early Antiretroviral Therapy in HIV-infected Infants: Evaluation After 2 Years of Treatment in the Pediacam Study, Cameroon. Pediatr Infect Dis J janv. 2018;37(1):78.

44. Chiappini E, Galli L, Tovo P-A, Gabiano C, Lisi C, Bernardi S, et al. Five-year follow-up of children with perinatal HIV-1 infection receiving early highly active antiretroviral therapy. BMC Infect Dis 26 août. 2009;9(1):1.

45. Tassie J-M, Baijal P, Vitoria MA, Alisalad A, Crowley SP, Souteyrand Y. Trends in retention on antiretroviral therapy in national programs in low-income and middle-income countries. J Acquir Immune Defic Syndr 1999 août. 2010;54(4):437-41.

46. Rouet F, Fassinou P, Inwoley A, Anaky M-F, Kouakoussui A, Rouzioux $C$, et al. Long-term survival and immuno-virological response of African HIV-1-infected children to highly active antiretroviral therapy regimens. AIDS Lond Engl. nov 2006;28(18):2315-9. 20(.

47. Tejiokem MC, Faye A, Penda IC, Guemkam G, Ateba Ndongo F, Chewa G, et al. Feasibility of Early Infant Diagnosis of HIV in Resource-Limited Settings: The ANRS 12140-PEDIACAM Study in Cameroon. Myer L, éditeur. PLoS ONE 19 juill. 2011;6(7):e21840.

48. Puthanakit T, Aurpibul L, Oberdorfer P, Akarathum N, Kanjananit S, Wannarit P, et al. Hospitalization and Mortality among HIV-Infected Children after Receiving Highly Active Antiretroviral Therapy. Clin Infect Dis 15 févr. 2007;44(4):599-604.

49. Dijk JH van, Sutcliffe CG, Munsanje B, Sinywimaanzi P, Hamangaba F, Thuma PE, et al. HIV-Infected Children in Rural Zambia Achieve Good Immunologic and Virologic Outcomes Two Years after Initiating Antiretroviral Therapy. PLOS ONE avr. 2011;6(4):e19006.

50. Weigel R, Estill J, Egger M, Harries AD, Makombe S, Tweya H, et al. Mortality and loss to follow-up in the first year of ART: Malawi national ART programme. AIDS Lond Engl 28 janv. 2012;26(3):365-73.

51. Polis MA, Sidorov IA, Yoder C, Jankelevich S, Metcalf J, Mueller BU, et al. Correlation between reduction in plasma HIV-1 RNA concentration 1 week after start of antiretroviral treatment and longer-term efficacy. Lancet Lond Engl 24 nov. 2001;358(9295):1760-5.

\section{Figures}




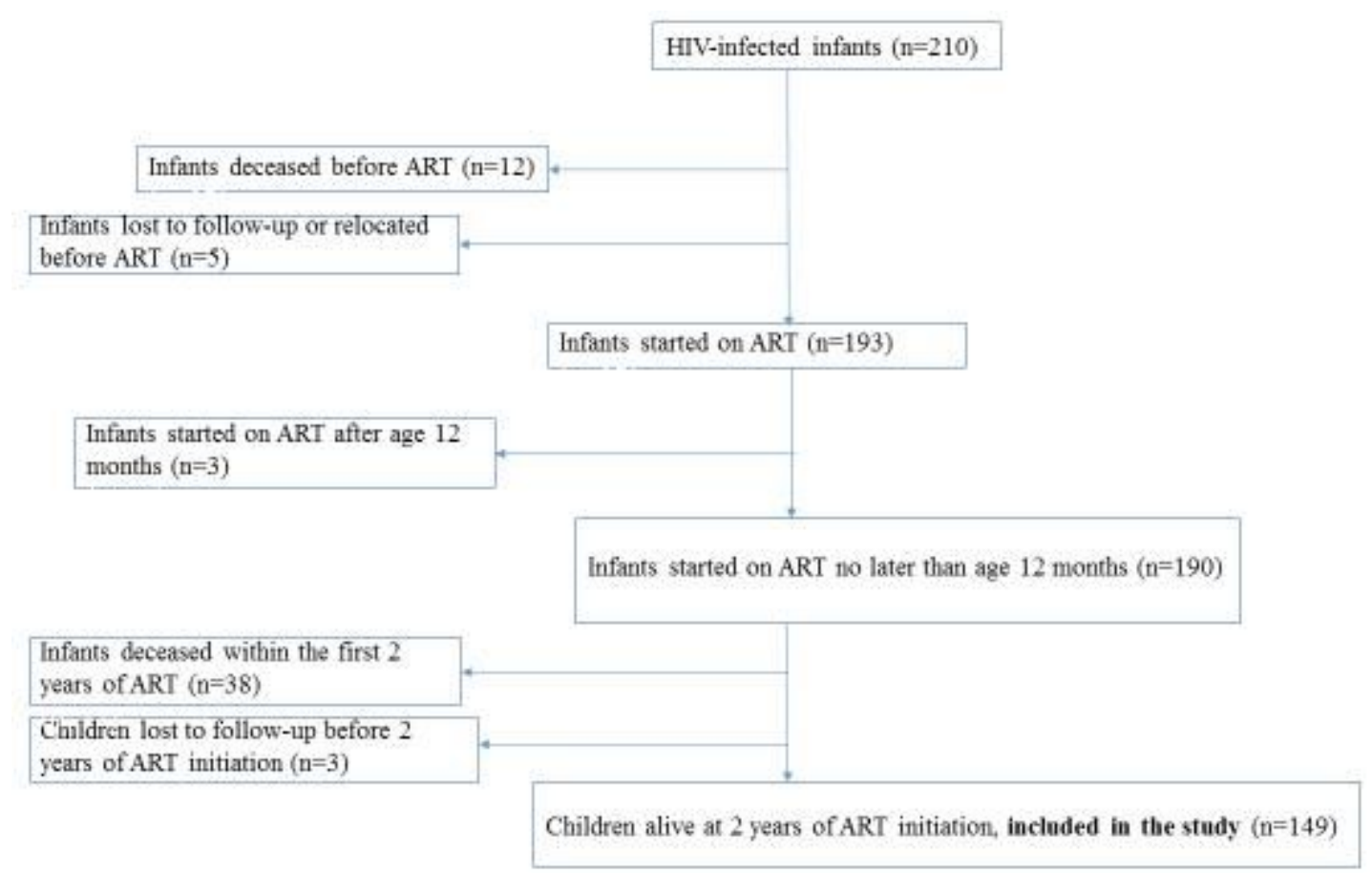

\section{Figure 1}

Flow chart of HIV-infected infants initiating ART (ANRS-Pediacam Study, 2008-2013, Cameroon) ART: Antiretroviral therapy 


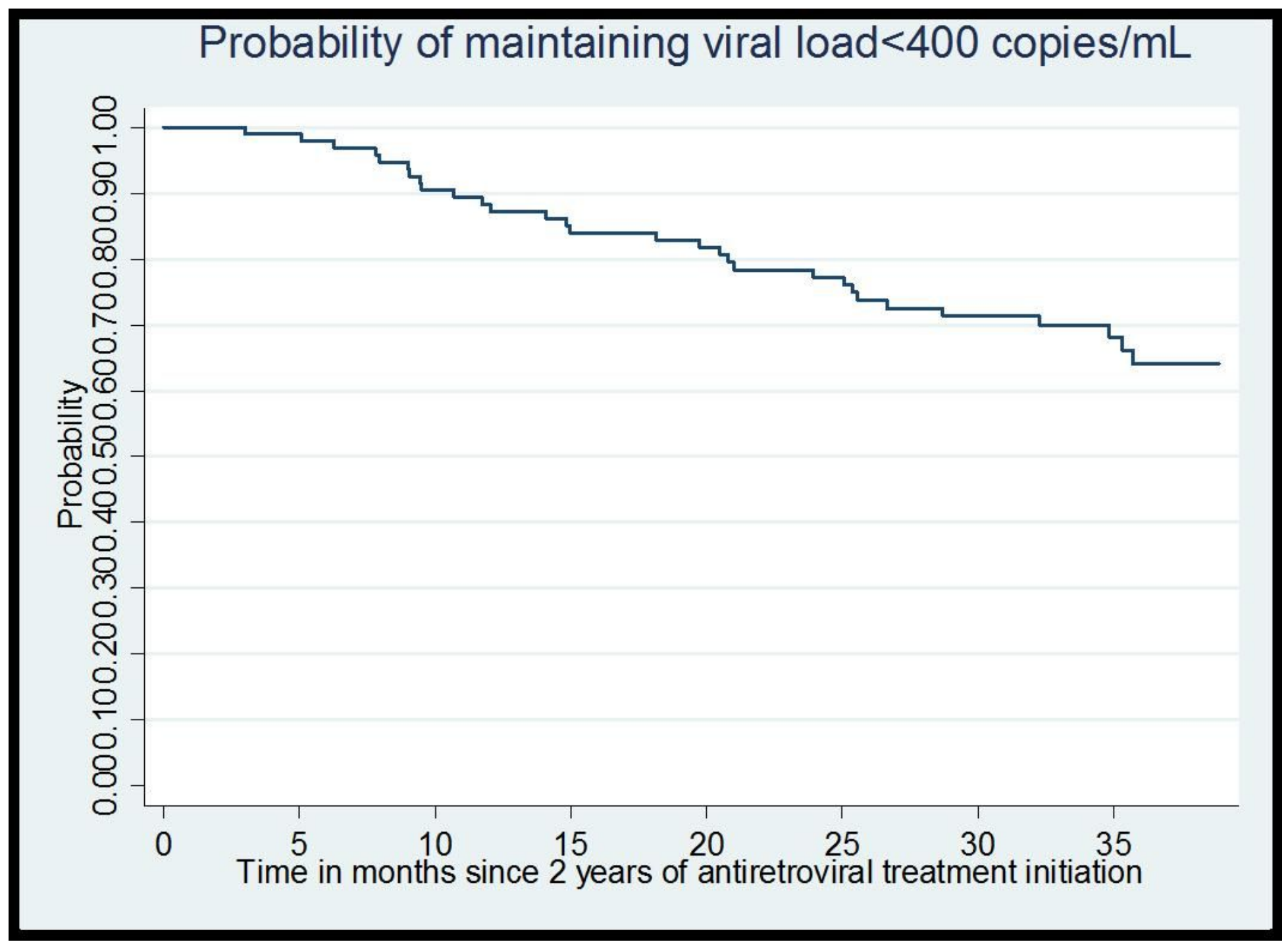

Figure 2

Kaplan-Meier curve: probability of maintaining a viral load $<400$ copies $/ \mathrm{mL}$ between 2 and 5 years after antiretroviral treatment initiation among the 90 children with a viral load $<400$ copies $/ \mathrm{mL}$ at 2 years after antiretroviral treatment initiation (ANRS-Pediacam Study, 2008-2013, Cameroon) 